\title{
Type 2 diabetes genes - Present status and data from Norwegian studies
}

\author{
Jens K. Hertel ${ }^{1,2,3,4}$, Stefan Johansson ${ }^{1,5}$, Kristian Midthjell ${ }^{6}$, Ottar Nygård ${ }^{1,3,7}$, \\ Pål R. Njølstad ${ }^{1,2,8}$ and Anders Molven ${ }^{1,9,10}$ \\ 1) KG Jebsen Center for Diabetes Research, University of Bergen \\ 2) Department of Clinical Medicine, University of Bergen \\ 3) Department of Heart Disease, Haukeland University Hospital, Bergen \\ 4) Morbid Obesity Center, Vestfold Hospital Trust, Tønsberg \\ 5) Center for Medical Genetics and Molecular Medicine, Haukeland University Hospital, Bergen \\ 6) Department of Public Health and General Practice, Norwegian University of Science and Technology, \\ HUNT Research Centre, Levanger \\ 7) Institute of Medicine, University of Bergen \\ 8) Department of Pediatrics, Haukeland University Hospital, Bergen \\ 9) The Gade Institute, University of Bergen \\ 10) Department of Pathology, Haukeland University Hospital, Bergen \\ Correspondence: Dr. Jens K. Hertel, KG Jebsen Center for Diabetes Research, University of Bergen, Haukeland University Hospital, \\ N-5021 Bergen, Norway \\ E-mail: jens.hertel@pedi.uib.no or jehert@siv.no
}

\begin{abstract}
The worldwide rise in prevalence of type 2 diabetes has led to an intense search for the genetic risk factors of this disease. In type 2 diabetes and other complex disorders, multiple genetic and environmental factors, as well as the interaction between these factors, determine the phenotype. In this review, we summarize present knowledge, generated by more than two decades of efforts to dissect the genetic architecture of type 2 diabetes. Initial studies were either based on a candidate gene approach or attempted to fine-map signals generated from linkage analysis. Despite the detection of multiple genomic regions proposed to be linked to type 2 diabetes, subsequent positional fine-mapping of candidates were mostly inconclusive. However, the introduction of genome-wide association studies (GWAS), applied on thousands of patients and controls, completely changed the field. To date, more than 50 susceptibility loci for type 2 diabetes have been detected through the establishment of large research consortia, the application of GWAS on intermediary diabetes phenotypes and the use of study samples of different ethnicities. Still, the common variants identified in the GWAS era only explain some of the heritability seen for type 2 diabetes. Thus, focus is now shifting towards searching also for rare variants using new high-throughput sequencing technologies. For genes involved in the genetic predisposition to type 2 diabetes the emerging picture is that there are hundreds of different gene variants working in a complex interplay influencing pancreatic beta cell function/mass and, only to a lesser extent, insulin action. Several Norwegian studies have contributed to the field, extending our understanding of genetic risk factors in type 2 diabetes and in diabetes-related phenotypes like obesity and cardiovascular disease.
\end{abstract}

\section{TYPE 2 DIABETES - ETIOLOGY AND HERITABILITY}

Diabetes is a major global health problem due to dramatically increasing prevalence worldwide. Globally, the total number of people with diabetes is projected to rise from 285 million in 2010 to 439 million in 2030 corresponding to a predicted increase in prevalence from $6.4 \%$ to $7.7 \%$ (1). The etiology of type 2 diabetes is not fully understood, but presumably, type 2 diabetes mainly develops when a diabetogenic lifestyle (i.e. excessive caloric intake, inadequate caloric expenditure, obesity) acts in conjugation with a susceptible genotype. Even though there is some disparity regarding the reasons for the development of type 2 diabetes, most physicians and scientists agree that the major independent risk factors for developing the disease are: obesity, family history (first-degree relative), ethnicity (some ethnic groups have higher prevalence of diabetes), history of previous impaired glucose tolerance or impaired fasting glycemia, hypertension or dyslipidemia, physical inactivity, history of gestational diabetes, low birth weight as a result of the in utero environment, polycystic ovarian syndrome leading to insulin resistance, and finally, decline in insulin secretion due to advancing age (2).

The clinical assessment of type 2 diabetes has often incorporated genetic information in the form of family history. Family information helps to raise clinical awareness for an individual patient's risk of type 2 diabetes due to the strong heritability of this disease and the effect of shared environmental factors between close relatives. In contrast to a population risk of 5$10 \%$, family studies have estimated that the risk for 
type 2 diabetes among offspring is 3.5 -fold and 6-fold higher for those with a single diabetic parent and two diabetic parents, respectively, compared with offspring without parental diabetes (3). Furthermore, the higher concordance rate of type 2 diabetes in monozygotic versus dizygotic twins and the high prevalence of type 2 diabetes in specific ethnic groups such as Pima Indians and Mexican Americans, all lend support to the existence of genetic determinants for type 2 diabetes (4). Overall, estimates have shown that $30-70 \%$ of type 2 diabetes risk can be ascribed to genetic factors (5). It is also evident, for example from a recent study in Finnish families, that type 2 diabetes-related intermediate and quantitative traits show substantial heritability (6). The patterns of inheritance therefore suggest that type 2 diabetes and its related traits are both polygenic and heterogeneous; hence multiple genes are involved and different combinations of genes play a role in different subsets of individuals. How many risk genes that exist and what their relative contributions are, remains somewhat uncertain despite the recent advances in dissecting the complex genetic architecture of type 2 diabetes. The purpose of this paper is to summarize the present knowledge of genetic risk factors in type 2 diabetes with emphasis on recent Norwegian data.

\section{GENETICS OF TYPE 2 DIABETES}

Several different approaches have been used in the exploration of genetic factors involved in type 2 diabetes. Progress has generally been guided by technological advances in genotyping and sequencing techniques, and in statistical handling of data. Also the collection of large patient cohorts amendable for genetic studies has been crucial.

In general, two methods have been used for studying genetic factors involved in human diseases in the $20^{\text {th }}$ century: the so-called candidate gene approach and the linkage analysis approach (7-9). The candidate gene approach examines specific genes with a plausible role in the disease process. For diabetes, natural candidates are genes involved in glucose homeostasis and metabolism. The approach is biased since it assumes that a specific gene or locus is associated with disease before testing. Genetic variants are identified through focused sequencing and further assessed by genotyping in a large number of cases and controls. Even though this approach has contributed to the identification of numerous published associations, only a fraction of the associations have been replicated by follow-up studies $(10,11)$.

The most robust candidate variants reported were the E23K variant in the KCNJI1 gene (12-14), the $\mathrm{P} 12 \mathrm{~A}$ variant in the peroxisome proliferator-activated receptor- $\gamma(P P A R G)$ gene (15), and common variants in the HNF1B and the Wolfram syndrome 1 (WFSI) genes (16-18). Notably, rare mutations in all four genes cause monogenic forms of diabetes (19-22), and two are targets of anti-diabetic therapies. KCNJI1 encodes a component of the $\beta$-cell potassium channel that is a target for the sulphonylurea class of drugs, and $P P A R G$ encodes a transcription factor involved in adipocyte differentiation that is a target for the thiazolidinedione class of drugs $(4,23)$.

In contrast to the candidate gene approach, linkage analysis is not based on assumptions, but identifies genes through their genomic position. The rationale is that family members sharing a specific phenotype also will share chromosomal regions surrounding the gene involved. The linkage approach has proved very effective in the identification of rare variants with large effects and high penetrance, i.e. those responsible for monogenic (Mendelian) disorders - including maturityonset diabetes of the young (MODY), mitochondrial diabetes with deafness, neonatal diabetes and rare forms of severe childhood obesity (24-26).

However, because the risk for relatives is smaller in complex diseases due to the low penetrance of polygenic risk variants, the statistical power of the linkage approach in studies of polygenic traits is limited (27). Even for loci with considerable effects on susceptibility at the population level, the number of families needed to offer sound power to detect linkage has proven hard to obtain (28). In addition, very few genetic variants with large phenotypic effect appear to be present in common complex diseases. Thus, most linkage studies have, in retrospect, been seriously underpowered. This probably also explains the lack of replication of published linkage regions. Moreover, when evidence of linkage has been observed, the genomic region linked to the trait of interest is often very large. Hence the identification of the causal gene or genetic variant remains the main challenge. There is one notable exception: the transcription factor 7-like 2 gene (TCF7L2). In 2006, the Icelandic company deCODE Genetics identified a common type 2 diabetes susceptibility variant in the $T C F 7 L 2$ gene region by linkage analysis (29). TCF7L2 was a completely unexpected type 2 diabetes gene, demonstrating that a genomewide approach could uncover previously unknown disease pathways (23).

In summary, the methods used successfully to identify the genes underlying Mendelian inherited diseases generally failed in the identification of the genetic basis of type 2 diabetes. This suggested that most of the genetic contribution to this disorder arises from multiple loci with individually small effects (Figure 1). The conceptual outline for association studies to identify common genetic variants underlying common complex diseases is referred to as the common disease/ common variant $(\mathrm{CD} / \mathrm{CV})$ hypothesis. The major assumption behind the $\mathrm{CD} / \mathrm{CV}$ hypothesis is that since the major diseases are common, so are the genetic variants that cause them. Moreover, common variants with low penetrance and modest risk are not subjected to the same negative selection as variants with strong phenotypic effect causing Mendelian diseases. Hence, the hypothesis states that common diseases are caused 


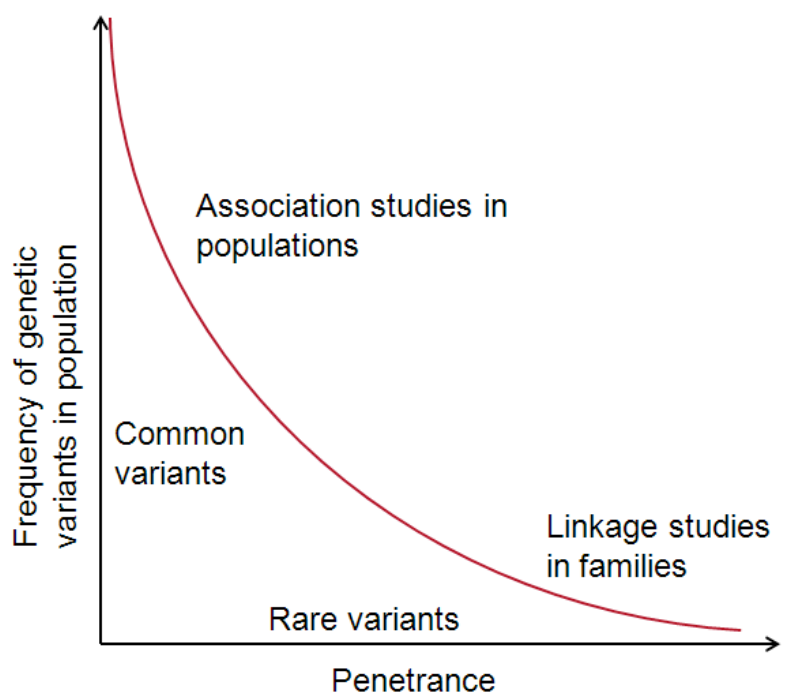

Figure 1. The allelic spectrum of disease - it is all about number, frequency and penetrance. The allelic spectrum of disease relies on the number of genetic variants, their frequency in a population and their penetrance (size of phenotypic effect). Linkage studies have proved successful in identifying genetic variants causing rare Mendelian disorders, i.e. those caused by low-frequency variants with high penetrance. On the genetic level, complex diseases are believed to be caused by multiple variants, each conferring only low to modest risk for disease. Modified and redrawn from (30).

by multiple, high frequency genetic variants conferring cumulative incremental effects on disease risk $(30,31)$. With these assumptions as a fundament, the next challenge became clear - to survey common genetic variants in the genomes of a large number of individuals.

The breakthrough came in 2006-2007 with the successful implementation of genome-wide association studies (GWAS). This new approach became possible as a result of the completion of the human genome sequence in 2001 (32,33), the creation of single nucleotide polymorphisms (SNP) linkage disequilibrium (LD) maps by the International HapMap Project (34) and great advancements in microarray-based genotyping technology and statistical tools (35). Using SNPbased arrays and comparing the frequency of SNP alleles between large numbers of cases and controls, the GWA approach allowed the investigators to detect genetic variants with modest phenotypic effects in a systematic and unbiased manner, provided that the variants had a high frequency in the population. Due to the vast amount of genetic variants analyzed in a GWAS, a high number of statistical tests are performed. This leads to a substantial risk of false positives owing to multiple testing and a much more stringent significance level is required before an association is considered statistically significant. Current consensus has, based on a simulation study, defined a genomewide significance level of $\mathrm{P}<5 \times 10^{-8}$ to account for $10^{6}$ independent genome-wide hypotheses tested in a dense GWAS (36).

In the spring of 2007, the results from the first wave of GWA studies investigating type 2 diabetes genes were published, namely the French, deCODE, DGI, WTCCC and FUSION studies (37-41). These five independent GWA studies were all conducted using a two-stage strategy consisting of a GWA screen in an initial cohort of unrelated cases and controls followed by replication of the most significant findings in additional patient series. The initial GWAS were followed by five smaller GWA studies (42-46). Each of these early GWA studies of type 2 diabetes identified numerous potential susceptibility variants and nine loci were consistently associated with disease risk across multiple studies. The nine loci were solute carrier family 30, member 8 (SLC30A8), hematopoietically expressed homeobox (HHEX), CDK5 regulatory subunit-associated protein 1-like 1 (CDKAL1), cyclindependent kinase inhibitor 2A/2B $(C D K N 2 A / B)$, insulin-like growth factor $2 \mathrm{mRNA}$-binding protein 2 $(I G F 2 B P 2)$, fat mass- and obesity-associated gene (FTO), TCF7L2, KCNJ11 and PPARG, among which the latter three had previously been implicated in type 2 diabetes (see above).

The TCF7L2 gene is the most strongly associated type 2 diabetes susceptibility gene found to date (29). Since its discovery, the association has been replicated in a variety of studies in subjects of different ethnicities (47). In the U.K. population, lead SNP has a frequency of $30 \%$ and the allelic odds ratio (OR) is 1.36 . Individuals carrying two risk $(\mathrm{T})$ alleles are at nearly twice the risk of type 2 diabetes as are those with none (48). TCF7L2 encodes a transcription factor in the Wnt-signaling pathway, which induces transcription of a number of genes, including proglucagon, in the intestine. Recent studies have shown that there is an increased expression of TCF $7 L 2$ in the islets of pancreas in type 2 diabetes, which in turn results in impaired glucose-stimulated insulin secretion (49).

The French GWA study involved non-obese diabetic patients and revealed that a gene encoding a protein that transports zinc in the pancreas, SLC 30A8, could increase the risk of type 2 diabetes (39). Of all the new type 2 diabetes genes discovered by the GWAS approach, SLC30A8 is one of the few involving an amino acid change - an arginine to tryptophan substitution at amino acid 325. Most other genes identified by GWAS would not be considered typical candidate genes for type 2 diabetes and in most cases the variants are located in non-coding regions within or near the gene.

In the first wave of GWAS, all studies had sample sizes in the range of one to two thousand and were therefore to some extent statistically underpowered to detect variants with small effect sizes. In recognition of this, data from three GWA studies were combined by the DIAGRAM consortium. Through meta-analysis followed by large-scale replication, six additional type 2 diabetes susceptibility genes were detected (see Table 1) (50). Initial GWAS were mainly performed in cases and controls from European populations. For this reason studies in other populations were warranted. 
Table 1. Genetic regions (variants) associated with type 2 diabetes at genome-wide levels of statistical significance $\left(\mathrm{p}<10^{-8}\right)$ per June 2012, listed by chromosome. Data in this table are adapted from $(4,64,116-118)$.

\begin{tabular}{|c|c|c|c|}
\hline Chr & $\begin{array}{l}\text { Gene region (lead } \\
\text { SNP) }\end{array}$ & $\begin{array}{l}\text { Discovery method (major } \\
\text { ethnicity) }\end{array}$ & $\begin{array}{l}\text { Cellular function and putative intermediary mechanism in } \\
\text { diabetes }\end{array}$ \\
\hline 1 & $\begin{array}{l}\text { PROX1 } \\
(\mathrm{rs} 340874)\end{array}$ & $\begin{array}{l}\text { Follow-up of signals for T2D from } \\
\text { GWA scan for FG (European) }\end{array}$ & $\begin{array}{l}\text { Encodes the prospero-related homeobox 1. Implicated in cell } \\
\text { proliferation and development. Associated with elevated FG. }\end{array}$ \\
\hline 1 & $\begin{array}{l}\text { NOTCH2 } \\
(\text { rs10923931) }\end{array}$ & GWA meta-analysis (European) & $\begin{array}{l}\text { Transmembrane receptor implicated in pancreatic organogenesis; } \\
\text { regulates cell differentiation. }\end{array}$ \\
\hline 2 & $\begin{array}{l}\text { GRB14 } \\
(\mathrm{rs} 3923113)\end{array}$ & $\begin{array}{l}\text { GWA meta-analysis (South } \\
\text { Asians) }\end{array}$ & $\begin{array}{l}\text { Adaptor protein binding to insulin receptor and insulin-like growth } \\
\text { factor receptors to inhibit kinase signaling. Associated with } \\
\text { reduced insulin sensitivity. }\end{array}$ \\
\hline 2 & $\begin{array}{l}\boldsymbol{B C L 1 1 A} \\
(\mathrm{rs} 243021)\end{array}$ & GWA meta-analysis (European) & $\begin{array}{l}\text { Involved in both B- and T-lymphocyte development and } \beta \text {-cell } \\
\text { function. Affects insulin response to glucose. }\end{array}$ \\
\hline 2 & $\begin{array}{l}\boldsymbol{R B M S 1} \\
(\mathrm{rs} 7593730)\end{array}$ & GWA meta-analysis (European) & $\begin{array}{l}\text { Encodes RNA-binding motif, single-stranded interacting protein } 1 . \\
\text { Implicated in DNA replication, gene transcription, cell cycle } \\
\text { progression and apoptosis. Unknown diabetogenic mechanism. }\end{array}$ \\
\hline 2 & $\begin{array}{l}\boldsymbol{G C K R} \\
(\mathrm{rs} 780094)\end{array}$ & $\begin{array}{l}\text { Follow-up of signals for T2D from } \\
\text { GWA scan for FG (European) }\end{array}$ & $\begin{array}{l}\text { Glucokinase regulatory protein. Involved in signal transduction, } \\
\text { glucose transport and sensing. Associated with FG, fasting insulin } \\
\text { and HOMA-IR. }\end{array}$ \\
\hline 2 & $\begin{array}{l}\text { IRS1 } \\
(\mathrm{rs} 2943641)\end{array}$ & $\begin{array}{l}\text { Single GWA study (French, } \\
\text { European) }\end{array}$ & $\begin{array}{l}\text { Encodes insulin receptor substrate-1. Associates with reduced } \\
\text { adiposity and impaired metabolic profile (e.g. visceral to } \\
\text { subcutaneous fat ratio, IR, dyslipidemia, CVD, adiponectin levels). }\end{array}$ \\
\hline 2 & $\begin{array}{l}\text { THADA } \\
(\text { (rs } 7578597)\end{array}$ & GWA meta-analysis (European) & $\begin{array}{l}\text { Thyroid adenoma-associated gene. Associates with PPAR; } \\
\text { Involved in apoptosis. Associated with } \beta \text {-cell dysfunction, lower } \beta \text { - } \\
\text { cell response to GLP- } 1 \text { and reduced } \beta \text {-cell mass. }\end{array}$ \\
\hline 3 & $\begin{array}{l}\text { ST6GAL1 } \\
(\mathrm{rs} 16861329)\end{array}$ & $\begin{array}{l}\text { GWA meta-analysis (South } \\
\text { Asians) }\end{array}$ & $\begin{array}{l}\text { Enzyme located in Golgi apparatus, involved in post-translational } \\
\text { modification of cell-surface components by glycosylation. }\end{array}$ \\
\hline 3 & $\begin{array}{l}\text { ADCY5 } \\
\text { (rs11708067) }\end{array}$ & $\begin{array}{l}\text { Follow-up of signals for T2D from } \\
\text { GWA scan for FG (European) }\end{array}$ & $\begin{array}{l}\text { Encodes adenylate cyclase } 5 \text {. Involved in signal transduction. } \\
\text { Associated with elevated FG. }\end{array}$ \\
\hline 3 & $\begin{array}{l}\text { ADAMTS9 } \\
\text { (rs4607103) }\end{array}$ & GWA meta-analysis (European) & $\begin{array}{l}\text { Proteolytic enzyme. Affects insulin response to glucose. Primary } \\
\text { effect on insulin action not driven by obesity. }\end{array}$ \\
\hline 3 & $\begin{array}{l}\boldsymbol{I G F 2 B P 2} \\
(\mathrm{rs} 4402960)\end{array}$ & Single GWA study (European) & $\begin{array}{l}\text { Growth factor (IGF2-mRNA) binding protein. Involved in } \\
\text { pancreatic development and stimulation of insulin action. }\end{array}$ \\
\hline 3 & $\begin{array}{l}\boldsymbol{P P A R G}^{*} \\
(\mathrm{rs} 1801282)\end{array}$ & $\begin{array}{l}\text { Candidate study; Later } \\
\text { confirmation by GWA studies }\end{array}$ & $\begin{array}{l}\text { TRF involved i adipocyte development. TRF receptor for TZDs } \\
\text { and prostaglandins. Effect on IR. }\end{array}$ \\
\hline 4 & $\begin{array}{l}\text { WFS } 1^{*} \\
(\mathrm{rs} 1801214)\end{array}$ & $\begin{array}{l}\text { Candidate study; later validated by } \\
\text { GWA meta-analysis }\end{array}$ & $\begin{array}{l}\text { Endoplasmic reticulum transmembrane protein involved in stress } \\
\text { and } \beta \text {-cell apoptosis. Insulin response. }\end{array}$ \\
\hline 5 & $\begin{array}{l}\text { ZBED3 } \\
\text { (rs4457053) }\end{array}$ & GWA meta-analysis (European) & $\begin{array}{l}\text { Encodes an axin-interacting protein activating wnt/beta-catenin } \\
\text { signaling. Unknown diabetogenic mechanism. }\end{array}$ \\
\hline 6 & $\begin{array}{l}\text { CDKAL1 } \\
\text { (rs7754840) }\end{array}$ & $\begin{array}{l}\text { Single GWA study (Icelandic, } \\
\text { European) }\end{array}$ & $\begin{array}{l}\text { Cyklin kinase (CDK5) inhibitor. Involved in cell cycle regulation } \\
\text { in the } \beta \text {-cell. Insulin response. }\end{array}$ \\
\hline 7 & $\begin{array}{l}\boldsymbol{K L F 1 4} \\
(\mathrm{rs} 972283)\end{array}$ & GWA meta-analysis (European) & $\begin{array}{l}\text { Basic transcription element-binding protein. "Master switch" } \\
\text { controlling other genes associated with BMI, insulin, glucose and } \\
\text { cholesterol. }\end{array}$ \\
\hline 7 & $\begin{array}{l}\boldsymbol{D G K B} \\
(\mathrm{rs} 972283)\end{array}$ & $\begin{array}{l}\text { Follow-up of signals for T2D from } \\
\text { GWA scan for FG (European) }\end{array}$ & $\begin{array}{l}\text { Encodes diacylglycerol kinase beta. Implicated in signal } \\
\text { transduction. Associated with elevated FG. }\end{array}$ \\
\hline 7 & $\begin{array}{l}\boldsymbol{G C} K^{*} \\
(\mathrm{rs} 4607517)\end{array}$ & $\begin{array}{l}\text { Follow-up of signals for T2D from } \\
\text { GWA scan for FG (European) }\end{array}$ & $\begin{array}{l}\text { Encodes the enzyme glucokinase. Involved in signal transduction, } \\
\text { glucose transport and sensing. Associated with elevated FG and } \\
\text { HbAlc. }\end{array}$ \\
\hline 7 & $\begin{array}{l}\boldsymbol{J A Z F 1} \\
(\mathrm{rs} 864745)\end{array}$ & GWA meta-analysis (European) & $\begin{array}{l}\text { Zinc-finger protein. Function as a transcriptional repressor. } \\
\text { Associated with prostate cancer. Insulin response. }\end{array}$ \\
\hline 8 & $\begin{array}{l}\text { TP53INP1 } \\
(\text { rs896854) }\end{array}$ & GWA meta-analysis (European) & $\begin{array}{l}\text { Encodes the p53-dependent damage-inducible nuclear protein. May } \\
\text { regulate p53-dependent apoptosis. Unknown diabetogenic } \\
\text { mechanism. }\end{array}$ \\
\hline 8 & $\begin{array}{l}\text { SLC30A8 } \\
(\mathrm{rs} 13266634)\end{array}$ & $\begin{array}{l}\text { Single GWA study (French, } \\
\text { European) }\end{array}$ & $\begin{array}{l}\beta \text {-cell zinc transporter ZnT8. Involved in insulin storage and } \\
\text { secretion. Associated with fasting proinsulin levels. }\end{array}$ \\
\hline 9 & $\begin{array}{l}\text { TLE }^{\mathrm{a}} \\
(\mathrm{rs} 13292136)\end{array}$ & GWA meta-analysis (European) & $\begin{array}{l}\text { Encodes the transducin-like enhancer of split } 4 \text {. Unknown } \\
\text { diabetogenic mechanism. }\end{array}$ \\
\hline 9 & $\begin{array}{l}\text { PTPRD } \\
(\text { rs } 17584499)\end{array}$ & Single GWA study (Taiwanese) & $\begin{array}{l}\text { Encodes the tyrosine phosphatase receptor type D protein. } \\
\text { Associated with increased HOMA-IR and may affect insulin } \\
\text { signaling on its target cells. }\end{array}$ \\
\hline 9 & $\begin{array}{l}\boldsymbol{C D K N 2 A / B} \\
(\operatorname{rs} 10811661)\end{array}$ & Single GWA study (European) & $\begin{array}{l}\text { Cyclin-dependent kinase inhibitor and p } 15 / 16 \text { tumor suppressor. } \\
\text { Involved in islet development. Also associated with CVD and } \\
\text { several cancers. Insulin response. }\end{array}$ \\
\hline
\end{tabular}




\begin{tabular}{|c|c|c|c|}
\hline Chr & \begin{tabular}{|l|} 
Gene region (lead \\
SNP) \\
\end{tabular} & $\begin{array}{l}\text { Discovery method (major } \\
\text { ethnicity) }\end{array}$ & $\begin{array}{l}\text { Cellular function and putative intermediary mechanism in } \\
\text { diabetes }\end{array}$ \\
\hline 10 & $\begin{array}{l}\text { VPS26A } \\
(\mathrm{rs} 1802295)\end{array}$ & $\begin{array}{l}\text { GWA meta-analysis (South } \\
\text { Asians) }\end{array}$ & $\begin{array}{l}\text { Multimeric protein involved in transport of proteins from } \\
\text { endosomes to the trans-Golgi network. Expressed in pancreatic and } \\
\text { adipose tissues. }\end{array}$ \\
\hline 10 & $\begin{array}{l}\text { CDC123 } \\
(\text { rs } 12779790)\end{array}$ & GWA meta-analysis (European) & $\begin{array}{l}\text { Cell cycle kinase, required for S-phase entry. Affects different } \\
\text { aspects of insulin response to glucose. }\end{array}$ \\
\hline 10 & $\begin{array}{l}\text { HHEX } \\
(\mathrm{rs} 1111875)\end{array}$ & $\begin{array}{l}\text { Single GWA study (French, } \\
\text { European) }\end{array}$ & $\begin{array}{l}\text { TRF involved i pancreatic development. Might influence both } \\
\text { insulin release and insulin sensitivity. }\end{array}$ \\
\hline 10 & \begin{tabular}{|l|}
$\boldsymbol{T C F 7 L 2}$ \\
$(\mathrm{rs} 7903146)$
\end{tabular} & $\begin{array}{l}\text { Linkage study; later confirmation } \\
\text { by several GWAs (European) }\end{array}$ & $\begin{array}{l}\text { TRF involved in wnt-signaling. Influencing insulin and glucagon } \\
\text { secretion. Most important polygene identified for T2D. }\end{array}$ \\
\hline 11 & $\begin{array}{l}\boldsymbol{A R A P I}^{\mathrm{b}} \\
\text { (rs1552224) }\end{array}$ & GWA meta-analysis (European) & $\begin{array}{l}\text { Associated with lower proinsulin levels, as well as lower } \beta \text {-cell } \\
\text { function (HOMA-B and insulinogenic index). }\end{array}$ \\
\hline 11 & $\begin{array}{l}\text { HMGA2 } \\
(\mathrm{rs} 1531343)\end{array}$ & GWA meta-analysis (European) & $\begin{array}{l}\text { Oncogene implicated in body size (height). Primary effect on } \\
\text { insulin action not driven by obesity. }\end{array}$ \\
\hline 11 & \begin{tabular}{|l|} 
MTNR1B \\
$(\mathrm{rs} 10830963)$
\end{tabular} & $\begin{array}{l}\text { Follow-up of signals for T2D from } \\
\text { GWA scan for FG or IS }\end{array}$ & $\begin{array}{l}\text { Receptor for melatonin. Involved in glucose homeostasis. } \\
\text { Associated with increased FG and reduced } \beta \text {-cell function. }\end{array}$ \\
\hline 11 & $\begin{array}{l}\text { KCNQ1 } \\
(\mathrm{rs} 2237892 \\
\mathrm{rs} 231362)^{\mathrm{c}}\end{array}$ & $\begin{array}{l}\text { Single GWA study (Japanese, } \\
\text { Asian, European) }\end{array}$ & $\begin{array}{l}\text { Encodes the pore-forming alfa subunit of } \mathrm{I}_{\mathrm{Ka}} \mathrm{K}^{+} \text {channel. Insulin } \\
\text { response. }\end{array}$ \\
\hline 11 & $\begin{array}{c}\text { KCNJ11* } \\
(\mathrm{rs} 5219)\end{array}$ & $\begin{array}{l}\text { Candidate study; later confirmation } \\
\text { by GWAS }\end{array}$ & $\begin{array}{l}\text { Inwardly rectifying potassium channel. Risk allele impairs insulin } \\
\text { secretion. }\end{array}$ \\
\hline 12 & $\begin{array}{l}\text { HNF1A* } \\
\text { (rs7957197) }\end{array}$ & $\begin{array}{l}\text { Candidate study; Later } \\
\text { confirmation by GWA meta- } \\
\text { analysis (European) }\end{array}$ & TRF essential for pancreatic $\beta$-cell development and function. \\
\hline 12 & \begin{tabular}{|l|} 
TSPAN8 \\
(rs7961581)
\end{tabular} & GWA meta-analysis (European) & $\begin{array}{l}\text { Cell surface glycoprotein implicated in GI cancers. Insulin } \\
\text { response. }\end{array}$ \\
\hline 13 & $\begin{array}{l}\text { SPRY2 } \\
(\mathrm{rs} 1359730)\end{array}$ & Single GWA study (Chinese) & $\begin{array}{l}\text { Inhibitor of tyrosine kinase signaling. Associated with body fat } \\
\text { percentage. Homologs inhibit insulin receptor-transduced MAPK } \\
\text { signaling. Regulates development of pancreas. }\end{array}$ \\
\hline 15 & $\begin{array}{l}\text { AP3S2 } \\
\text { (rs2028299) }\end{array}$ & $\begin{array}{l}\text { GWA meta-analysis (South } \\
\text { Asians) }\end{array}$ & $\begin{array}{l}\text { Clathrin-associated adaptor complex expressed in adipocytes and } \\
\text { pancreatic islets. Involved in vesicle transport and sorting. } \\
\text { Unknown diabetogenic mechanism }\end{array}$ \\
\hline 15 & $\begin{array}{l}\boldsymbol{H M G 2 0 A} \\
(\text { rs } 7178572)\end{array}$ & $\begin{array}{l}\text { GWA meta-analysis (South } \\
\text { Asians) }\end{array}$ & $\begin{array}{l}\text { High mobility group non-histone chromosomal protein influencing } \\
\text { histone methylation. Involved in neuronal development. Unknown } \\
\text { diabetogenic mechanism. }\end{array}$ \\
\hline 15 & $\begin{array}{l}\text { C2CD4A } \\
(\text { rs } 11071657)\end{array}$ & Single GWA study (Japanese) & $\begin{array}{l}\text { Nuclear calcium-dependent domain-containing protein. Impairs } \\
\text { glucose-stimulated insulin response. Associated with levels of } \\
\text { fasting glucose and proinsulin. }\end{array}$ \\
\hline 15 & \begin{tabular}{|l|} 
ZFAND6 \\
(rs11634397)
\end{tabular} & GWA meta-analysis (European) & $\begin{array}{l}\text { Encodes a zinc finger AN1 Domain-containing protein. Unknown } \\
\text { diabetogenic mechanism. }\end{array}$ \\
\hline 15 & $\begin{array}{l}\text { PRC1 } \\
(\mathrm{rs} 8042680)\end{array}$ & GWA meta-analysis (European) & Protein regulating cytokinesis. Unknown diabetogenic mechanism. \\
\hline 16 & $\begin{array}{l}\text { FTO } \\
(\text { rs } 8050136 \\
\text { rs9939609) } \\
\end{array}$ & $\begin{array}{l}\text { Single GWA study (British, } \\
\text { European) }\end{array}$ & $\begin{array}{l}\text { 2-oxoglutarate-dependent demethylase. Alters BMI i general } \\
\text { population. }\end{array}$ \\
\hline 17 & $\begin{array}{l}\boldsymbol{S R R} \\
(\mathrm{rs} 391300)\end{array}$ & Single GWA study (Taiwanese) & $\begin{array}{l}\text { Encodes a serine racemase protein. May play a role in regulation of } \\
\text { insulin and glucagon secretion. }\end{array}$ \\
\hline 17 & $\begin{array}{l}\boldsymbol{H N F 1 B} * \\
(\operatorname{rs} 757210)\end{array}$ & Candidate study & $\begin{array}{l}\text { TRF involved in development of the kidney, pancreas, liver, and } \\
\text { Mullerian duct. Implicated in MODY and renal cyst. Associated } \\
\text { with prostate cancer. }\end{array}$ \\
\hline 20 & $\begin{array}{l}\boldsymbol{H N F 4 A} \\
(\mathrm{rs} 4812829)\end{array}$ & $\begin{array}{l}\text { Candidate study; Later replicated } \\
\text { by GWA meta-analysis (South } \\
\text { Asians) }\end{array}$ & $\begin{array}{l}\text { Nuclear TRF expressed in liver. Regulates transcription of several } \\
\text { genes, e.g. HNF1A. Elevated hepatic glucose production. Defective } \\
\text { pancreatic } \beta \text {-cell function and impaired insulin secretion. }\end{array}$ \\
\hline $\mathbf{X}$ & $\begin{array}{l}\text { DUSP9 } \\
(\text { rs5945326) }\end{array}$ & GWA meta-analysis (European) & $\begin{array}{l}\text { MAP kinase phosphatase. Decreased insulin release for male risk } \\
\text { allele carriers. Up-regulated during adipocyte differentiation. } \\
\text { Involved in insulin signaling and stress induced IR. }\end{array}$ \\
\hline
\end{tabular}

All loci have shown genome-wide statistical significance $\left(\mathrm{p} \leq 10^{-8}\right)$. For many of the loci several SNPs associate with type 2 diabetes, but only one (in some cases two) SNPs are listed. Abbreviations: Chr: chromosome; CVD: cardiovascular disease; FG: fasting glucose; GI: gastrointestinal; IR: insulin resistance; IS: insulin secretion; T2D: type 2 diabetes; TRF: transcription factor; TZD: thiazolidinediones. ${ }^{a} \mathrm{GWA}$ signal re-annotated from $C H C H D 9$ to TLE4. ${ }^{\mathrm{b}}$ Formerly known as CENTD2. ${ }^{\mathrm{c}}$ These SNPs are in low LD in Europeans $\left(\mathrm{r}^{2}=0.01\right)$, thus they most likely represent two independent association signals. ${ }^{*}$ Genes also implicated in MODY, other monogenic forms of diabetes or rare genetic syndromes. 
The first GWAS performed in Asian subjects with type 2 diabetes discovered a new gene, $K C N Q 1$, which later has been confirmed also in European subjects $(51,52)$. Notably, most type 2 diabetes variants have been shown to have an impact on pancreatic $\beta$-cell function with a primary effect on insulin secretion rather than on insulin action (53). A GWAS performed in French and Danish subjects revealed, however, a variant in the IRSI gene, which together with $P P A R G$ belongs to the very few type 2 diabetes loci that display a diabetogenic potential by affecting peripheral insulin sensitivity (54).

The GWA approach has further demonstrated that genetic studies of glycemic traits can identify type 2 diabetes risk loci. GWAS for fasting glucose or insulin secretion revealed from 2008 to 2010 a whole new set of type 2 diabetes susceptibility loci. The melatoninreceptor gene (MTNR1B), which highlights the link between circadian and metabolic regulation (55), was found to be associated with levels of fasting glucose and risk of type 2 diabetes (56-58). Follow-up signals of a fourth GWA scan for fasting glucose identified, in addition to $M T N R 1 B$, five other loci associated with type 2 diabetes (59). Recently, several studies have reported even larger meta-analyses of GWA data from both European and Asian ethnic groups, leading to the identification of several new loci for type 2 diabetes, including HNF1A and HNF4A (60-62). The confirmation of common variant associations at $H N F 1 A$ and $H N F 4 A$ added two new loci to those known to harbor both rare mutations causing monogenic forms of diabetes and common variants predisposing to multifactorial diabetes. The number is now seven, the others being PPARG, KCNJ11, WFS1, HNF1B and GCK.

In summary, GWAS have, by establishing large research consortia, performing meta-analyses, using intermediary diabetes phenotypes (e.g. fasting glucose) and applying study samples of different ethnicities, delivered a whole set of new susceptibility loci for type 2 diabetes over the last five years, now counting over 50 loci $(60,63)$. The validated type 2 diabetes susceptibility loci along with their discovery method, cellular function and putative intermediary mechanism in diabetes are summarized in Table 1. The most recently reported type 2 diabetes susceptibility regions are individually only associated with a marginally increased risk for diabetes (odds ratio $<1.1$ ), and can together explain only $\sim 10 \%$ of the heritability seen for type 2 diabetes (64). Therefore, at present, the known type 2 diabetes variants do not add much extra information compared to clinical risk factors when it comes to individual prediction of the risk of diabetes development (65).

\section{NORWEGIAN STUDIES AND THEIR CONTRIBUTION}

The most frequent forms of monogenic diabetes (see article by Søvik et al. in this issue of the Norwegian Journal of Epidemiology) are caused by rare mutations in the genes HNF1A, GCK, HNF4A and HNF1B (66$68)$. Naturally, common variants in these genes would be plausible candidates involved in glucose homeostasis and metabolism, including type 2 diabetes. Some, but not all, studies found an association between common variants near the $H N F 4 A \mathrm{P} 2$ promoter and type 2 diabetes. In an attempt to address these inconsistencies, Johansson et al. (69) investigated HNF4A SNPs in a large population-based sample of individuals with type 2 diabetes and control subjects from the NordTrøndelag Health Studies and included a meta-analysis of published studies. The results suggested that variation in the HNF4A region is associated with type 2 diabetes in Scandinavians, highlighting the importance of exploring small genetic effects in large, homogenous populations.

A further study conducted by Thorsby et al. (70) studied the impact of four candidate polymorphisms in the three well-known type 2 diabetes susceptibility genes TCF7L2, PPARG and $K C N J 11$ on traditional risk factors for type 2 diabetes in a sample from HUNT, using both cross-sectional and prospective design. The two investigated risk alleles of the TCF7L2 gene were strongly associated with type 2 diabetes, even after controlling for traditional risk factors. These risk alleles were associated with indices of reduced betacell function. The population attributable risks for diabetes with $T C F 7 L 2$ risk alleles were $15 \%$ and with diabetes in a first-degree relative $31 \%$.

The GWAS wave provided substantial support for several new type 2 diabetes susceptibility variants. However, these studies were mainly performed in carefully selected cases (sometimes the extremes of the phenotype) and controls. To get a better estimate of the true effects conferred by these susceptibility loci, Hertel et al. (71) used a completely unselected population of type 2 diabetic persons and controls from the HUNT2 Survey. They confirmed the association with type 2 diabetes for three SNPs in or near the genes $C D K N 2 B, F T O$ and $S L C 30 A 8$, and observed a borderline significant association for the variant near $I G F 2 B P 2$. The size effects that were observed in this study are close to the estimates from the previous studies, indicating that the design of the first GWAS round seems to pinpoint risk-alleles that show generality, at least in other Northern European populations.

In the spring of 2007, several independent GWAS papers reported a strong correlation between body mass index and SNPs in the human FTO gene $(38,72-$ $74)$. This association was initially seen in a study of type 2 diabetes. The diabetogenic effect, however, proved to be mediated through adiposity. Common variants in the first FTO intron define a risk allele predisposing to both childhood and adult obesity, where homozygotes for the risk allele weigh approximately 3 kilograms more and having a 1.67 -fold increased risk of obesity compared to homozygotes for the protective allele (73). These findings have been extensively reproduced and the effect is fairly consistent throughout 
different study populations (reviewed in (75)). The FTO risk variants have also shown association with obesity-related conditions and diseases such as the metabolic syndrome, polycystic ovary syndrome (PCOS), and type 2 diabetes (76-78). However, in most of the studies reported, these effects appear to be secondary to weight increase since the associations are attenuated or completely abolished after adjusting for BMI (78).

In our first study using samples from HUNT (71), we replicated the association for the same FTO variant (rs9939609), both with regard to BMI and type 2 diabetes. Interestingly, the association between rs9939609 and type 2 diabetes and BMI remained significant after adjustment for BMI and diabetes status, respectively. It is also noteworthy that rs9939609 demonstrated a strong association with triacylglycerol levels, which was not abolished after correcting for diabetes status. Thus, our data suggested that the relation between FTO and $\mathrm{BMI} /$ diabetes is more complex than initially thought.

We therefore initiated a Nordic collaborative project with two Swedish research groups having access to both extensive clinical and genetic data from the Malmö Preventive Project (MPP) and Malmö Diet and Cancer (MDC) cohorts. Through this collaboration we aimed to investigate whether a variant in FTO affects type 2 diabetes risk entirely through its effect on BMI and how FTO influences BMI across adult life span in 41,504 subjects from the Scandinavian HUNT, MDC and MPP studies. In one of the largest studies to date investigating the effect of FTO sequence variants on type 2 diabetes and BMI, we demonstrated that FTO does not mediate type 2 diabetes risk entirely through its influence on BMI (79). In an attempt to capture the complex relationship between FTO, BMI, and type 2 diabetes during the life course, we also performed an analysis on incident type 2 diabetes in over 20,000 non-diabetic individuals followed up for over 10 years. Over 3,000 developed type 2 diabetes during followup, and the FTO variant was strongly associated with the incident risk of type 2 diabetes. The results remained similar when we controlled for BMI at baseline (before diabetes was diagnosed), $\triangle \mathrm{BMI}$, or waist circumference and/or waist-to-hip ratio as covariates in the regression analyses. None of the covariates alone or in combination with BMI changed our results notably: FTO still conferred an increased risk for type 2 diabetes. This study supports that FTO not only is an obesity gene, but also a type 2 diabetes susceptibility gene.

The meta-analysis of the FTO-associated allelewise effect on BMI using cross-sectional data from the HUNT, MPP and MDC studies confirmed the strong effect of the FTO SNP on BMI $\left(0.28 \mathrm{~kg} / \mathrm{m}^{2}\right.$ per risk allele, $\mathrm{P}=2.0 \times 10^{-26}$ ), with no significant heterogeneity in the effect sizes for the risk allele between different adult age groups. Interestingly, using longitudinal data from the HUNT and MPP studies, we found no differences in change of BMI over time according to rs9939609 risk allele status. Hence, our results indicate that the additional weight gain as a result of the FTO risk variant seems to occur relatively early in life, most likely before adulthood, and the relative BMI difference remains stable thereafter (79).

After the identification of a disease-associated region by GWAS, comprehensive studies of sequence variation in the region are essential to identify the full set of variants that might explain the association signal. This is due to the fact that a GWAS is neither a candidate-gene approach nor directly intended to detect causative variants. Non-coding variants at human chromosome 9p21 near $C D K N 2 A$ and $C D K N 2 B$ have repeatedly been associated with type 2 diabetes (37, $38,41,50)$, myocardial infarction (80-82), aneurysm (83), stroke (84) and at least five types of cancers (85$90)$. Hence, this region appears as one of the most interesting regions to emerge from the first-generation of GWAS. In a recently submitted paper (91) we applied a genetic fin-mapping approach by assessing 19 SNPs tagging a 138-kb region on chromosome 9p21 for association with type 2 diabetes, stroke, myocardial infarction, angina pectoris, and coronary heart disease. Through single point and haplotype analysis, we found evidence for only one common type 2 diabetes risk haplotype upstream of the $C D K N 2 B$ gene region. Furthermore, we confirmed the associations for SNPs in the $9 \mathrm{p} 21$ region with $\mathrm{MI}$, angina pectoris and coronary heart disease. Despite their close proximity, there seems to be no apparent overlap between the cardiovascular disease and type 2 diabetes risk regions. Theories with reference to the disease mechanism mediated by the causative risk variants of the $9 \mathrm{p} 21$ interval have increased in numbers during the last years. However, since most of them still remain to be explored, the exact nature of the causative variants and the target proteins or genes is still elusive.

As previously mentioned, GWAS meta-analyses, establishment of large consortia, examination of intermediary diabetes phenotypes and study samples of different ethnicities, have greatly extended the number of known type 2 diabetes risk loci. Also several Norwegian scientists have through the last five years contributed in large multi-center consortia (DIAGRAM, MAGIC, GIANT) with their experience and with samples from the HUNT Survey. Genome-wide analyses and meta-analyses of these data have revealed several novel type 2 diabetes susceptibility loci and the results are consistent with a long tail of additional common variant loci explaining much of the variation in susceptibility to type 2 diabetes $(50,62,92-98)$.

Definition and accuracy of the phenotype is one of the key issues in designing any genetic study. To increase the chance of finding relevant susceptibility genes for complex diseases, one may have to look more narrowly and start dissecting them according to their pathophysiology or clinical characteristics. In contrast to genome-wide searches, genetic analysis of an intermediate or low-level phenotype is eased by 
greater proximity to the genetic variant, thus reducing the effects of other factors surrounding and possibly influencing the effect of individual genes (99). Poor glucose control (expressed as high $\mathrm{HbA}_{1 \mathrm{c}}$ ) is a wellknown risk factor for long-term diabetic complications and has for a long time been recognized as an interesting intermediate phenotype in relation to diabetes. There is variability in glycemic control both between and within individuals, and $\mathrm{HbA}_{1 \mathrm{c}}$ have a heritability estimate that makes it a phenotype suited for genetic analysis $(100,101)$. We have evaluated whether four novel SNPs (from the SORCS1, BNC2, GSC and $W D R 72$ genes) reported to affect $\mathrm{HbA}_{1 \mathrm{c}}$ levels in subjects with type 1 diabetes (102) had an effect on glycemia in a type 2 diabetes cohort (103). We observed allele frequencies similar to the frequencies reported in individuals with type 1 diabetes. However, in the individual SNP analysis, no significant associations with $\mathrm{HbA}_{1 \mathrm{c}}$ or glucose levels were found for the analyzed variants. Although the observed effects were nonsignificant and of much smaller magnitude than previously reported in type 1 diabetes, the SORCSI risk variant showed a direction consistent with increased $\mathrm{HbA}_{1 \mathrm{c}}$ and glucose levels, with an observed effect of $0.11 \%$ and $0.13 \mathrm{mmol} / 1$ increase per risk allele for $\mathrm{HbA}_{1 \mathrm{c}}$ and glucose, respectively. In contrast, the WDR72 risk variant showed a borderline association with reduced $\mathrm{HbA}_{1 \mathrm{c}}$ levels, and direction consistent with decreased glucose levels. When we included all four variants in a combined genetic score model, we observed no evidence for a relationship between increasing number of risk alleles and increasing $\mathrm{HbA}_{\mathrm{lc}}$ or glucose levels. Each additional risk allele demonstrated an increase in $\mathrm{HbA}_{1 \mathrm{c}}$ of approximately $0.04 \%$ (103).

The different pathophysiology between type 1 and type 2 diabetes could be one explanation why our results did not support that the four investigated loci are genetic susceptibility factors for glycemic control in type 2 diabetes. In the future, it will be important to expand the study of genetic influences on $\mathrm{HbA}_{1 \mathrm{c}}$ to pre-diabetic and diabetic populations, even though the confounding effects of treatment might obscure any role of these polymorphisms in the diabetic population. Initiatives dissecting the genetic influences of $\mathrm{HbA}_{1 \mathrm{c}}$ levels will be important not only to better understand the genetic and biologic determinants of $\mathrm{HbA}_{1 \mathrm{c}}$ variation in the general population better, but it could also be important in the present initiatives to use $\mathrm{HbA}_{1 \mathrm{c}}$ as a diagnostic tool for diabetes $(104,105)$.

It has been discussed whether latent autoimmune diabetes of adults (LADA) is a mild form of type 1 diabetes or a distinct etiological entity. Both clinical and genetic studies have, however, shown that the etiology of LADA resembles partly type 1 and partly type 2 diabetes (for more information about LADA see article by $\mathrm{S}$. Carlsson et al. in this issue). Pettersen et al. (106) tested for association of known type 1 and type 2 diabetes susceptibility genes in LADA subjects assembled from the HUNT survey, and analyzed relationships to a marker of autoimmune activity (titers of anti-GAD) and a phenotypic risk factor of type 2 diabetes (BMI). The majority of the strongly associated $H L A$ haplotypes for type 1 diabetes were significantly associated with LADA in general, but mainly with high anti-GAD LADA patients. Two distinct $H L A$ haplotypes were associated only with LADA and mainly in low anti-GAD LADA patients. There were no associations of non-HLA type 1 diabetes loci with LADA. Of type 2 diabetes-associated genes, the variant rs7961581 near TSPAN8 and the obesity-linked variant rs8050136 in FTO were associated with LADA in general, but mainly in low anti-GAD LADA patients. This study demonstrated that the genetic heterogeneity in LADA is linked to various degrees of autoimmune activity and may be partly distinct from both type 1 and type 2 diabetes.

Several genes implicated in MODY has been validated as type 2 diabetes genes through GWAS (see Table 1). Mutations in the HNF1A gene are the most common cause of MODY, and there is a substantial variation in the age at diabetes diagnosis, even within families where diabetes is caused by the same mutation. In a recent study using data from two study centers (Exeter, UK and the Norwegian MODY registry) we therefore investigated the hypothesis that common polygenic variants that predispose to type 2 diabetes might account for the difference in age at diagnosis in HNF1A-MODY (107). In a sample of 410 individuals with a known mutation in the $H N F 1 A$ gene, the effect of 15 robustly associated type 2 diabetes variants on the age at diagnosis was assessed, both individually and in a combined genetic score. We observed that each risk variant for type 2 diabetes was found to lower the age of MODY onset by 0.35 years, independent of other genetic and environmental modifiers. Thus, this is one of the first studies to demonstrate that clinical characteristics of a monogenic disease (i.e. MODY) can be influenced by common variants that predispose to the polygenic form of that disease (i.e. common type 2 diabetes). There will definitely be more examples to come $(107,108)$.

\section{CONCLUDING REMARKS AND FUTURE PERSPECTIVES}

The aim of this review was to summarize the present status regarding the complex genetic nature and architecture of type 2 diabetes. By reviewing the international literature and recent Norwegian studies it is evident that there has been a tremendous progress during the last five years regarding the dissection of the genetic background of type 2 diabetes as well as of diabetes-related phenotypes. Although GWAS have provided some new biological insights, only a limited amount of the heritable component has been identified and it remains a challenge to clarify the functional link between associated variants and phenotypic traits. It is, nevertheless, crucial to continue to perform in-depth 


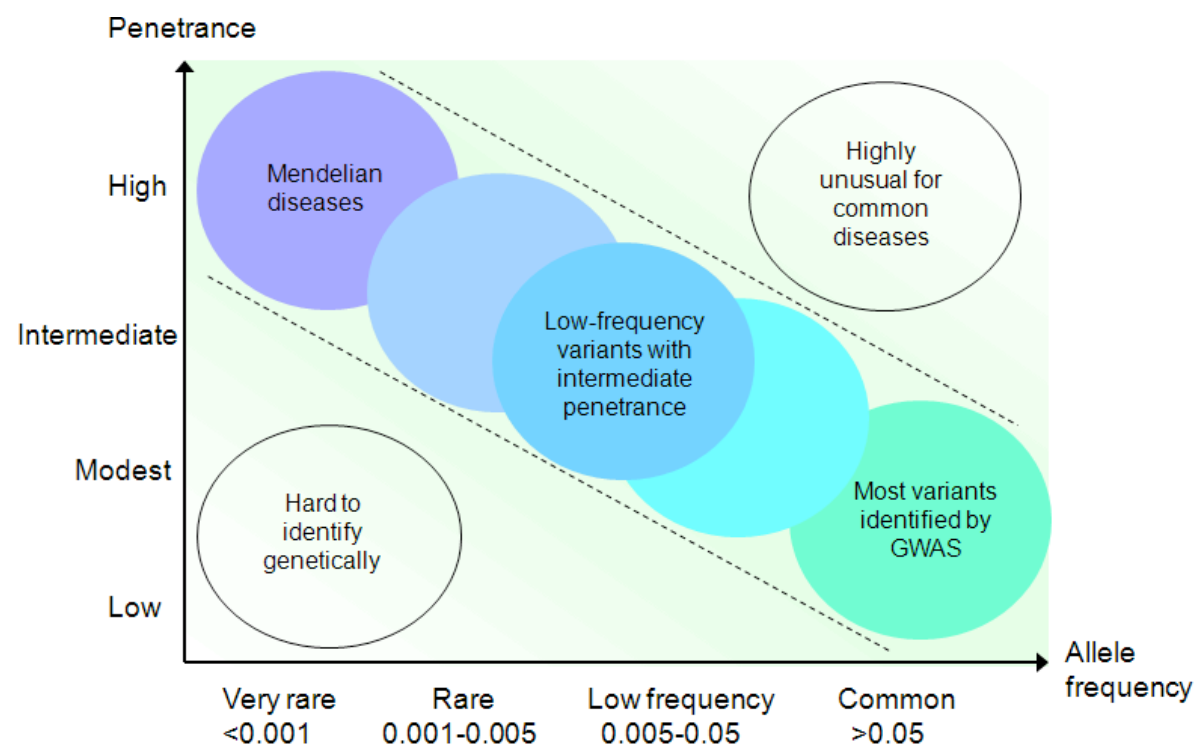

Figure 2. Possibility of identifying genetic variants by risk allele frequency and penetrance (strength of genetic effect). Frequency and the effect are essential factors when it comes to the likelihood of detecting genetic variants. Most emphasis lies in identifying genetic associations with characteristics shown within the diagonal lines. Future research adapting next-generation sequencing strategies will in particular focus on identifying low-frequency variants with intermediate penetrance. Modified and redrawn from (109).

follow-up studies for these and future susceptibility loci in unselected samples of patients and control participants, since inclusion criteria such as age of onset, family history of the trait or BMI may affect the type of loci detected.

The current generation of GWAS tags common SNPs to some extent adequately, but is less efficient in detecting SNPs of lower allele frequency or in technologically difficult genomic regions (109). These limitations have been widely recognized and it now seems likely that the genetics of common diseases also involve rare and un-catalogued variants with individually somewhat stronger effects on risk (Figure 2) (110). Recent advances in next-generation sequencing technologies might facilitate substantial progress here. Both exome-sequencing and whole-genome sequencing are currently being performed in large samples of different ethnicities and will hopefully contribute to identification of rare variants involved in type 2 diabetes and serve as a reference for other studies.

As an example, GWAS have revealed that common non-coding variants in the $M T N R 1 B$ gene increase type 2 diabetes risk $(56,57)$. Although the strongest association signal was highly significant, its contribution to type 2 diabetes risk was only modest (OR of $\sim 1.10$ 1.15 ). By performing large-scale exon re-sequencing in 7,632 Europeans, including 2,186 individuals with type 2 diabetes, Bonnefond et al. (111) identified 40 non-synonymous variants, including 36 very rare variants (MAF $<0.1 \%$ ), associated with type 2 diabetes. Four of these were very rare with complete loss of melatonin binding and signaling capabilities. This study establishes a link, both genetically and functionally, between the MTNRIB gene and type 2 diabetes risk, and further highlights the importance of rare variants in health and disease.

Another way to identify rare genetic variants with expectedly large effects is to study families with some accumulation of disease. Genetic variations that cause disease will occur with higher frequency in the affected relatives than in a reference population. Exomesequencing will then be an appropriate approach for tracking down the gene variations, as recently demonstrated for the MITF gene and malignant melanoma (112). Sequencing of families with extreme quantitative traits could also be an important next step in the dissection of the genetics of type 2 diabetes.

Finally, most genetic research has an overall aim of translating the findings into progression in clinical care. The mechanistic insights generated by gene discovery might identify new therapeutic targets and lead to novel pharmaceutical and preventative approaches. This was shown for those patients who could switch from insulin to oral sulfonylureas due to rare mutations in $K C N J 11(113,114)$. Moreover, loss of function variants that reduce the risk for disease may also provide hypotheses for new therapeutic strategies, an approach used to design cholesterol-lowering drugs based on genetic findings in PCSK9 (115). In addition, there is a growing belief that individual patterns of genetic predisposition will be valuable in health-care delivery and contribute to the development of a more personalized medicine. However, the development of personalized medicine beyond monogenic diseases requires a more complete picture of the genetic predisposition and the disease mechanisms. Hopefully, in a few years, largescale genome-wide re-sequencing efforts have provided a systematic and a more complete description of the associations between genome sequence variation and major clinical phenotypes like type 2 diabetes. 


\section{REFERENCES}

1. Shaw JE, Sicree RA, Zimmet PZ. Global estimates of the prevalence of diabetes for 2010 and 2030. Diabetes Res Clin Pract 2009; 87 (1): 4-14.

2. Chen L, Magliano DJ, Zimmet PZ. The worldwide epidemiology of type 2 diabetes mellitus - present and future perspectives. Nat Rev Endocrinol 2011; 8 (4): 228-36.

3. Meigs JB, Cupples LA, Wilson PW. Parental transmission of type 2 diabetes: the Framingham Offspring Study. Diabetes 2000; 49 (12): 2201-7.

4. Doria A, Patti ME, Kahn CR. The emerging genetic architecture of type 2 diabetes. Cell Metab 2008; 8 (3): $186-200$

5. Poulsen P, Kyvik KO, Vaag A, Beck-Nielsen H. Heritability of type II (non-insulin-dependent) diabetes mellitus and abnormal glucose tolerance - a population-based twin study. Diabetologia 1999; 42 (2): 139-45.

6. Almgren P, Lehtovirta M, Isomaa B, Sarelin L, Taskinen MR, Lyssenko V, et al. Heritability and familiality of type 2 diabetes and related quantitative traits in the Botnia Study. Diabetologia 2011; 54: 2811-9.

7. Hattersley AT, McCarthy MI. What makes a good genetic association study? Lancet 2005; 366 (9493): 131523.

8. Hopper JL, Bishop DT, Easton DF. Population-based family studies in genetic epidemiology. Lancet 2005; 366 (9494): 1397-406.

9. McCarthy MI. Growing evidence for diabetes susceptibility genes from genome scan data. Curr Diab Rep 2003; 3 (2): 159-67.

10. Lohmueller KE, Pearce CL, Pike M, Lander ES, Hirschhorn JN. Meta-analysis of genetic association studies supports a contribution of common variants to susceptibility to common disease. Nat Genet 2003; 33 (2): 17782.

11. Ioannidis JP, Ntzani EE, Trikalinos TA, Contopoulos-Ioannidis DG. Replication validity of genetic association studies. Nat Genet 2001; 29 (3): 306-9.

12. Florez JC, Burtt N, de Bakker PI, Almgren P, Tuomi T, Holmkvist J, et al. Haplotype structure and genotypephenotype correlations of the sulfonylurea receptor and the islet ATP-sensitive potassium channel gene region. Diabetes 2004; 53 (5): 1360-8.

13. Gloyn AL, Weedon MN, Owen KR, Turner MJ, Knight BA, Hitman G, et al. Large-scale association studies of variants in genes encoding the pancreatic beta-cell KATP channel subunits Kir6.2 (KCNJ11) and SUR1 (ABCC8) confirm that the KCNJ11 E23K variant is associated with type 2 diabetes. Diabetes 2003; 52 (2): $568-72$.

14. Nielsen EM, Hansen L, Carstensen B, Echwald SM, Drivsholm T, Glumer C, et al. The E23K variant of Kir6.2 associates with impaired post-OGTT serum insulin response and increased risk of type 2 diabetes. Diabetes 2003; 52 (2): 573-7.

15. Altshuler D, Hirschhorn JN, Klannemark M, Lindgren CM, Vohl MC, Nemesh J, et al. The common PPARgamma Pro12Ala polymorphism is associated with decreased risk of type 2 diabetes. Nat Genet 2000; 26 (1): 76-80.

16. Sandhu MS, Weedon MN, Fawcett KA, Wasson J, Debenham SL, Daly A, et al. Common variants in WFS1 confer risk of type 2 diabetes. Nat Genet 2007; 39: 951-3.

17. Gudmundsson J, Sulem P, Steinthorsdottir V, Bergthorsson JT, Thorleifsson G, Manolescu A, et al. Two variants on chromosome 17 confer prostate cancer risk, and the one in TCF2 protects against type 2 diabetes. Nat Genet 2007; 39 (8): 977-83.

18. Winckler W, Weedon MN, Graham RR, McCarroll SA, Purcell S, Almgren P, et al. Evaluation of common variants in the six known maturity-onset diabetes of the young (MODY) genes for association with type 2 diabetes. Diabetes 2007; 56 (3): 685-93.

19. Barroso I, Gurnell M, Crowley VE, Agostini M, Schwabe JW, Soos MA, et al. Dominant negative mutations in human PPARgamma associated with severe insulin resistance, diabetes mellitus and hypertension. Nature 1999; 402 (6764): 880-3.

20. Gloyn AL, Pearson ER, Antcliff JF, Proks P, Bruining GJ, Slingerland AS, et al. Activating mutations in the gene encoding the ATP-sensitive potassium-channel subunit Kir6.2 and permanent neonatal diabetes. $N$ Engl J Med 2004; 350 (18): 1838-49.

21. Inoue H, Tanizawa Y, Wasson J, Behn P, Kalidas K, Bernal-Mizrachi E, et al. A gene encoding a transmembrane protein is mutated in patients with diabetes mellitus and optic atrophy (Wolfram syndrome). Nat Genet 1998; 20 (2): 143-8.

22. Nishigori H, Yamada S, Kohama T, Tomura H, Sho K, Horikawa Y, et al. Frameshift mutation, A263fsinsGG, in the hepatocyte nuclear factor-1beta gene associated with diabetes and renal dysfunction. Diabetes 1998; 47 (8): 1354-5. 
23. Frayling TM. Genome-wide association studies provide new insights into type 2 diabetes aetiology. Nat Rev Genet 2007; 8 (9): 657-62.

24. Vaxillaire M, Froguel P. Genetic basis of maturity-onset diabetes of the young. Endocrinol Metab Clin North Am 2006; 35 (2): 371-84, x.

25. Waterfield T, Gloyn AL. Monogenic $\beta$-cell dysfunction in children: clinical phenotypes, genetic etiology and mutational pathways. Pediatric Health 2008; 2 (4): 517-32.

26. O'Rahilly S. Human genetics illuminates the paths to metabolic disease. Nature 2009; 462 (7271): 307-14.

27. Lander ES, Schork NJ. Genetic dissection of complex traits. Science 1994; 265 (5181): 2037-48.

28. Risch NJ. Searching for genetic determinants in the new millennium. Nature 2000; 405 (6788): 847-56.

29. Grant SF, Thorleifsson G, Reynisdottir I, Benediktsson R, Manolescu A, Sainz J, et al. Variant of transcription factor 7-like 2 (TCF7L2) gene confers risk of type 2 diabetes. Nat Genet 2006; 38 (3): 320-3.

30. Rahim NG, Harismendy O, Topol EJ, Frazer KA. Genetic determinants of phenotypic diversity in humans. Genome Biol 2008; 9 (4): 215.

31. Reich DE, Lander ES. On the allelic spectrum of human disease. Trends Genet 2001; 17 (9): 502-10.

32. Lander ES, Linton LM, Birren B, Nusbaum C, Zody MC, Baldwin J, et al. Initial sequencing and analysis of the human genome. Nature 2001; 409 (6822): 860-921.

33. Venter JC, Adams MD, Myers EW, Li PW, Mural RJ, Sutton GG, et al. The sequence of the human genome. Science 2001; 291 (5507): 1304-51.

34. Frazer KA, Ballinger DG, Cox DR, Hinds DA, Stuve LL, Gibbs RA, et al. A second generation human haplotype map of over 3.1 million SNPs. Nature 2007; 449 (7164): 851-61.

35. Altshuler D, Daly MJ, Lander ES. Genetic mapping in human disease. Science 2008; 322 (5903): 881-8.

36. Risch N, Merikangas K. The future of genetic studies of complex human diseases. Science 1996; 273 (5281): 1516-7.

37. Saxena R, Voight BF, Lyssenko V, Burtt NP, de Bakker PI, Chen H, et al. Genome-wide association analysis identifies loci for type 2 diabetes and triglyceride levels. Science 2007; 316 (5829): 1331-6.

38. Scott LJ, Mohlke KL, Bonnycastle LL, Willer CJ, Li Y, Duren WL, et al. A genome-wide association study of type 2 diabetes in Finns detects multiple susceptibility variants. Science 2007; 316 (5829): 1341-5.

39. Sladek R, Rocheleau G, Rung J, Dina C, Shen L, Serre D, et al. A genome-wide association study identifies novel risk loci for type 2 diabetes. Nature 2007; 445 (7130): 881-5.

40. Steinthorsdottir V, Thorleifsson G, Reynisdottir I, Benediktsson R, Jonsdottir T, Walters GB, et al. A variant in CDKAL1 influences insulin response and risk of type 2 diabetes. Nat Genet 2007; 39 (6): 770-5.

41. Zeggini E, Weedon MN, Lindgren CM, Frayling TM, Elliott KS, Lango H, et al. Replication of genome-wide association signals in UK samples reveals risk loci for type 2 diabetes. Science 2007; 316 (5829): 1336-41.

42. Florez JC, Manning AK, Dupuis J, McAteer J, Irenze K, Gianniny L, et al. A 100K genome-wide association scan for diabetes and related traits in the Framingham Heart Study: replication and integration with other genome-wide datasets. Diabetes 2007; 56 (12): 3063-74.

43. Hanson RL, Bogardus C, Duggan D, Kobes S, Knowlton M, Infante AM, et al. A search for variants associated with young-onset type 2 diabetes in American Indians in a 100K genotyping array. Diabetes $2007 ; 56$ (12): 3045-52.

44. Hayes MG, Pluzhnikov A, Miyake K, Sun Y, Ng MC, Roe CA, et al. Identification of type 2 diabetes genes in Mexican Americans through genome-wide association studies. Diabetes 2007; 56 (12): 3033-44.

45. Rampersaud E, Damcott CM, Fu M, Shen H, McArdle P, Shi X, et al. Identification of novel candidate genes for type 2 diabetes from a genome-wide association scan in the Old Order Amish: evidence for replication from diabetes-related quantitative traits and from independent populations. Diabetes 2007; 56 (12): 3053-62.

46. Salonen JT, Uimari P, Aalto JM, Pirskanen M, Kaikkonen J, Todorova B, et al. Type 2 diabetes whole-genome association study in four populations: the DiaGen consortium. Am J Hum Genet 2007; 81 (2): 338-45.

47. Zeggini E, McCarthy MI. TCF7L2: the biggest story in diabetes genetics since HLA? Diabetologia $2007 ; 50$ (1): $1-4$.

48. Groves CJ, Zeggini E, Minton J, Frayling TM, Weedon MN, Rayner NW, et al. Association analysis of 6,736 U.K. subjects provides replication and confirms TCF7L2 as a type 2 diabetes susceptibility gene with a substantial effect on individual risk. Diabetes 2006; 55 (9): 2640-4.

49. Lyssenko V, Lupi R, Marchetti P, Del Guerra S, Orho-Melander M, Almgren P, et al. Mechanisms by which common variants in the TCF7L2 gene increase risk of type 2 diabetes. J Clin Invest 2007; 117 (8): 2155-63.

50. Zeggini E, Scott LJ, Saxena R, Voight BF, Marchini JL, Hu T, et al. Meta-analysis of genome-wide association data and large-scale replication identifies additional susceptibility loci for type 2 diabetes. Nat Genet 2008; 40 (5): 638-45.

51. Unoki H, Takahashi A, Kawaguchi T, Hara K, Horikoshi M, Andersen G, et al. SNPs in KCNQ1 are associated with susceptibility to type 2 diabetes in East Asian and European populations. Nat Genet 2008; 40 (9): 1098-102. 
52. Yasuda K, Miyake K, Horikawa Y, Hara K, Osawa H, Furuta H, et al. Variants in KCNQ1 are associated with susceptibility to type 2 diabetes mellitus. Nat Genet 2008; 40 (9): 1092-7.

53. Florez JC. Newly identified loci highlight beta cell dysfunction as a key cause of type 2 diabetes: where are the insulin resistance genes? Diabetologia 2008; 51 (7): 1100-10.

54. Rung J, Cauchi S, Albrechtsen A, Shen L, Rocheleau G, Cavalcanti-Proenca C, et al. Genetic variant near IRS1 is associated with type 2 diabetes, insulin resistance and hyperinsulinemia. Nat Genet $2009 ; 41$ (10): 1110-5.

55. Mulder H, Nagorny CL, Lyssenko V, Groop L. Melatonin receptors in pancreatic islets: good morning to a novel type 2 diabetes gene. Diabetologia 2009; 52 (7): 1240-9.

56. Bouatia-Naji N, Bonnefond A, Cavalcanti-Proenca C, Sparso T, Holmkvist J, Marchand M, et al. A variant near MTNR1B is associated with increased fasting plasma glucose levels and type 2 diabetes risk. Nat Genet 2009; 41 (1): 89-94.

57. Lyssenko V, Nagorny CL, Erdos MR, Wierup N, Jonsson A, Spegel P, et al. Common variant in MTNR1B associated with increased risk of type 2 diabetes and impaired early insulin secretion. Nat Genet 2009; 41 (1): $82-8$.

58. Prokopenko I, Langenberg C, Florez JC, Saxena R, Soranzo N, Thorleifsson G, et al. Variants in MTNR1B influence fasting glucose levels. Nat Genet 2009; 41 (1): 77-81.

59. Dupuis J, Langenberg C, Prokopenko I, Saxena R, Soranzo N, Jackson AU, et al. New genetic loci implicated in fasting glucose homeostasis and their impact on type 2 diabetes risk. Nat Genet 2010; 42 (2): 105-16.

60. Kooner JS, Saleheen D, Sim X, Sehmi J, Zhang W, Frossard P, et al. Genome-wide association study in individuals of South Asian ancestry identifies six new type 2 diabetes susceptibility loci. Nat Genet 2011; 43 (10): 984-9.

61. Qi L, Cornelis MC, Kraft P, Stanya KJ, Linda Kao WH, Pankow JS, et al. Genetic variants at $2 \mathrm{q} 24$ are associated with susceptibility to type 2 diabetes. Hum Mol Genet 2010; 19 (13): 2706-15.

62. Voight BF, Scott LJ, Steinthorsdottir V, Morris AP, Dina C, Welch RP, et al. Twelve type 2 diabetes susceptibility loci identified through large-scale association analysis. Nat Genet 2010; 42 (7): 579-89.

63. McCarthy MI. Genomics, type 2 diabetes, and obesity. N Engl J Med 2010; 363 (24): 2339-50.

64. Billings LK, Florez JC. The genetics of type 2 diabetes: what have we learned from GWAS? Ann N Y Acad Sci 2010; 1212: 59-77.

65. Lyssenko V, Jonsson A, Almgren P, Pulizzi N, Isomaa B, Tuomi T, et al. Clinical risk factors, DNA variants, and the development of type 2 diabetes. N Engl J Med 2008; 359 (21): 2220-32.

66. Eide SA, Ræder H, Johansson S, Midthjell K, Søvik O, Njølstad PR, et al. Prevalence of HNF1A (MODY3) mutations in a Norwegian population (the HUNT2 Study). Diabet Med 2008; 25 (7): 775-81.

67. Murphy R, Ellard S, Hattersley AT. Clinical implications of a molecular genetic classification of monogenic beta-cell diabetes. Nat Clin Pract Endocrinol Metab 2008; 4 (4): 200-13.

68. Njølstad PR, Hertel JK, Søvik O, Ræder H, Johansson S, Molven A. [Progress in diabetes genetics]. Tidsskr Nor Laegeforen 2010; 130 (11): 1145-9.

69. Johansson S, Ræder H, Eide SA, Midthjell K, Hveem K, Søvik O, et al. Studies in 3,523 Norwegians and meta-analysis in 11,571 subjects indicate that variants in the hepatocyte nuclear factor 4 alpha (HNF4A) P2 region are associated with type 2 diabetes in Scandinavians. Diabetes 2007; 56 (12): 3112-7.

70. Thorsby PM, Midthjell K, Gjerlaugsen N, Holmen J, Hanssen KF, Birkeland KI, et al. Comparison of genetic risk in three candidate genes (TCF7L2, PPARG, KCNJ11) with traditional risk factors for type 2 diabetes in a population-based study - the HUNT study. Scand J Clin Lab Invest 2009; 69 (2): 282-7.

71. Hertel JK, Johansson S, Ræder H, Midthjell K, Lyssenko V, Groop L, et al. Genetic analysis of recently identified type 2 diabetes loci in 1,638 unselected patients with type 2 diabetes and 1,858 control participants from a Norwegian population-based cohort (the HUNT study). Diabetologia 2008; 51 (6): 971-7.

72. Dina C, Meyre D, Gallina S, Durand E, Korner A, Jacobson P, et al. Variation in FTO contributes to childhood obesity and severe adult obesity. Nat Genet 2007; 39 (6): 724-6.

73. Frayling TM, Timpson NJ, Weedon MN, Zeggini E, Freathy RM, Lindgren CM, et al. A common variant in the FTO gene is associated with body mass index and predisposes to childhood and adult obesity. Science 2007; 316 (5826): 889-94.

74. Scuteri A, Sanna S, Chen WM, Uda M, Albai G, Strait J, et al. Genome-wide association scan shows genetic variants in the FTO gene are associated with obesity-related traits. PLoS Genet 2007; 3 (7): e115.

75. Fawcett KA, Barroso I. The genetics of obesity: FTO leads the way. Trends Genet 2010; 26 (6): 266-74.

76. Al-Attar SA, Pollex RL, Ban MR, Young TK, Bjerregaard P, Anand SS, et al. Association between the FTO rs9939609 polymorphism and the metabolic syndrome in a non-Caucasian multi-ethnic sample. Cardiovasc Diabetol 2008; 7: 5 . 
77. Barber TM, Bennett AJ, Groves CJ, Sovio U, Ruokonen A, Martikainen H, et al. Association of variants in the fat mass and obesity associated (FTO) gene with polycystic ovary syndrome. Diabetologia 2008; 51 (7): 1153-8.

78. Freathy RM, Timpson NJ, Lawlor DA, Pouta A, Ben-Shlomo Y, Ruokonen A, et al. Common variation in the FTO gene alters diabetes-related metabolic traits to the extent expected given its effect on BMI. Diabetes 2008; 57 (5): 1419-26.

79. Hertel JK, Johansson S, Sonestedt E, Jonsson A, Lie RT, Platou CG, et al. FTO, type 2 diabetes, and weight gain throughout adult life: A meta-analysis of 41,504 subjects from the Scandinavian HUNT, MDC, and MPP studies. Diabetes 2011; 60 (5): 1637-44.

80. Helgadottir A, Thorleifsson G, Manolescu A, Gretarsdottir S, Blondal T, Jonasdottir A, et al. A common variant on chromosome 9p21 affects the risk of myocardial infarction. Science 2007; 316 (5830): 1491-3.

81. Kathiresan S, Voight BF, Purcell S, Musunuru K, Ardissino D, Mannucci PM, et al. Genome-wide association of early-onset myocardial infarction with single nucleotide polymorphisms and copy number variants. Nat Genet 2009; 41 (3): 334-41.

82. McPherson R, Pertsemlidis A, Kavaslar N, Stewart A, Roberts R, Cox DR, et al. A common allele on chromosome 9 associated with coronary heart disease. Science 2007; 316 (5830): 1488-91.

83. Helgadottir A, Thorleifsson G, Magnusson KP, Gretarsdottir S, Steinthorsdottir V, Manolescu A, et al. The same sequence variant on 9p21 associates with myocardial infarction, abdominal aortic aneurysm and intracranial aneurysm. Nat Genet 2008; 40 (2): 217-24.

84. Matarin M, Brown WM, Singleton A, Hardy JA, Meschia JF. Whole genome analyses suggest ischemic stroke and heart disease share an association with polymorphisms on chromosome 9p21. Stroke 2008; 39 (5): $1586-9$.

85. Falchi M, Bataille V, Hayward NK, Duffy DL, Bishop JA, Pastinen T, et al. Genome-wide association study identifies variants at 9p21 and 22q13 associated with development of cutaneous nevi. Nat Genet 2009; 41 (8): 915-9.

86. Sherborne AL, Hosking FJ, Prasad RB, Kumar R, Koehler R, Vijayakrishnan J, et al. Variation in CDKN2A at 9p21.3 influences childhood acute lymphoblastic leukemia risk. Nat Genet 2010; 42 (6): 492-4.

87. Shete S, Hosking FJ, Robertson LB, Dobbins SE, Sanson M, Malmer B, et al. Genome-wide association study identifies five susceptibility loci for glioma. Nat Genet 2009; 41 (8): 899-904.

88. Stacey SN, Sulem P, Masson G, Gudjonsson SA, Thorleifsson G, Jakobsdottir M, et al. New common variants affecting susceptibility to basal cell carcinoma. Nat Genet 2009; 41 (8): 909-14.

89. Turnbull C, Ahmed S, Morrison J, Pernet D, Renwick A, Maranian M, et al. Genome-wide association study identifies five new breast cancer susceptibility loci. Nat Genet 2010; 42 (6): 504-7.

90. Wrensch M, Jenkins RB, Chang JS, Yeh RF, Xiao Y, Decker PA, et al. Variants in the CDKN2B and RTEL1 regions are associated with high-grade glioma susceptibility. Nat Genet 2009; 41 (8): 905-8.

91. Hertel JK, Molven A, Ræder H, Platou C, Midthjell K, Hveem K, et al. Genetic fine-mapping of chromosome 9 p21 - a region associated with diabetes and cardiovascular disease in a population-based sample (the HUNT2 Survey). 2013, Manuscript submitted.

92. Cho YS, Chen CH, Hu C, Long J, Ong RT, Sim X, et al. Meta-analysis of genome-wide association studies identifies eight new loci for type 2 diabetes in east Asians. Nat Genet 2011; 44 (1): 67-72.

93. Dastani Z, Hivert MF, Timpson N, Perry JR, Yuan X, Scott RA, et al. Novel loci for adiponectin levels and their influence on type 2 diabetes and metabolic traits: a multi-ethnic meta-analysis of 45,891 individuals. PLoS Genet 2012; 8 (3): e1002607.

94. Imamura M, Maeda S, Yamauchi T, Hara K, Yasuda K, Morizono T, et al. A single-nucleotide polymorphism in ANK1 is associated with susceptibility to type 2 diabetes in Japanese populations. Hum Mol Genet 2012; 21 (13): 3042-9.

95. Kelly MA, Rees SD, Hydrie MZ, Shera AS, Bellary S, O'Hare JP, et al. Circadian gene variants and susceptibility to type 2 diabetes: a pilot study. PLoS One 2012; 7 (4): e32670.

96. Marquez M, Huyvaert M, Perry JR, Pearson RD, Falchi M, Morris AP, et al. Low-frequency variants in HMGA1 are not associated with type 2 diabetes risk. Diabetes 2012; 61 (2): 524-30.

97. Palmer ND, McDonough CW, Hicks PJ, Roh BH, Wing MR, An SS, et al. A genome-wide association search for type 2 diabetes genes in African Americans. PLoS One 2012; 7 (1): e29202.

98. Strawbridge RJ, Dupuis J, Prokopenko I, Barker A, Ahlqvist E, Rybin D, et al. Genome-wide association identifies nine common variants associated with fasting proinsulin levels and provides new insights into the pathophysiology of type 2 diabetes. Diabetes 2011; 60 (10): 2624-34.

99. Bougneres P. Genetics of obesity and type 2 diabetes: tracking pathogenic traits during the predisease period. Diabetes 2002; 51 (Suppl 3): S295-303.

100. Meigs JB, Panhuysen CI, Myers RH, Wilson PW, Cupples LA. A genome-wide scan for loci linked to plasma levels of glucose and $\mathrm{HbA}(1 \mathrm{c})$ in a community-based sample of Caucasian pedigrees: The Framingham Offspring Study. Diabetes 2002; 51 (3): 833-40. 
101. Pilia G, Chen WM, Scuteri A, Orru M, Albai G, Dei M, et al. Heritability of cardiovascular and personality traits in 6,148 Sardinians. PLoS Genet 2006; 2 (8): e132.

102. Paterson AD, Waggott D, Boright AP, Hosseini SM, Shen E, Sylvestre MP, et al. A genome-wide association study identifies a novel major locus for glycemic control in type 1 diabetes, as measured by both A1C and glucose. Diabetes 2010; 59 (2): 539-49.

103. Hertel JK, Johansson S, Ræder H, Platou CG, Midthjell K, Hveem K, et al. Evaluation of four novel genetic variants affecting hemoglobin A1c levels in a population-based type 2 diabetes cohort (the HUNT2 study). BMC Med Genet 2011; 12: 20.

104. Soranzo N. Genetic determinants of variability in glycated hemoglobin (HbA (1c)) in humans: review of recent progress and prospects for use in diabetes care. Curr Diab Rep 2011; 11: 562-9.

105. Use of glycated haemoglobin (HbAlc) in the diagnosis of diabetes mellitus. Abbreviated report of a WHO consultation. 2011: 25.

106. Pettersen E, Skorpen F, Kvaløy K, Midthjell K, Grill V. Genetic heterogeneity in latent autoimmune diabetes is linked to various degrees of autoimmune activity: results from the Nord-Trondelag Health Study. Diabetes 2010; 59 (1): 302-10.

107. Lango Allen H, Johansson S, Ellard S, Shields B, Hertel JK, Ræder H, et al. Polygenic risk variants for type 2 diabetes susceptibility modify age at diagnosis in monogenic HNF1A diabetes. Diabetes 2010; 59 (1): 266 71.

108. Molven A, Njølstad PR. Role of molecular genetics in transforming diagnosis of diabetes mellitus. Expert Rev Mol Diagn 2011; 11 (3): 313-20.

109. Manolio TA, Collins FS, Cox NJ, Goldstein DB, Hindorff LA, Hunter DJ, et al. Finding the missing heritability of complex diseases. Nature 2009; 461 (7265): 747-53.

110. Cirulli ET, Goldstein DB. Uncovering the roles of rare variants in common disease through whole-genome sequencing. Nat Rev Genet 2010; 11 (6): 415-25.

111. Bonnefond A, Clement N, Fawcett K, Yengo L, Vaillant E, Guillaume JL, et al. Rare MTNR1B variants impairing melatonin receptor 1B function contribute to type 2 diabetes. Nat Genet 2012; 44 (3): 297-301.

112. Yokoyama S, Woods SL, Boyle GM, Aoude LG, MacGregor S, Zismann V, et al. A novel recurrent mutation in MITF predisposes to familial and sporadic melanoma. Nature 2011; 480 (7375): 99-103.

113. Pearson ER, Flechtner I, Njølstad PR, Malecki MT, Flanagan SE, Larkin B, et al. Switching from insulin to oral sulfonylureas in patients with diabetes due to Kir6.2 mutations. N Engl J Med 2006; 355 (5): 467-77.

114. Sagen JV, Ræder H, Hathout E, Shehadeh N, Gudmundsson K, Bævre H, et al. Permanent neonatal diabetes due to mutations in KCNJ11 encoding Kir6.2: patient characteristics and initial response to sulfonylurea therapy. Diabetes 2004; 53 (10): 2713-8.

115. Kathiresan S, Srivastava D. Genetics of human cardiovascular disease. Cell 2012; 148 (6): 1242-57.

116. Cariaso M, Lennon G. SNPedia: a wiki supporting personal genome annotation, interpretation and analysis. Nucleic Acids Res 2012; 40 (Database issue): D1308-12.

117. Hindorff LA, Junkins HA, Hall PN, Mehta JP, TA M. A catalog of published genome-wide association studies. Available at: www.genome.gov/gwastudies. Accessed 09.25.2011.

118. Imamura M, Maeda S. Genetics of type 2 diabetes: the GWAS era and future perspectives. Endocr J 2011; 58 (9): 723-39. 